\title{
Is Patient Education About Adhesions a Requirement in Abdominopelvic Surgery?
}

\section{Besteht bei abdominopelvinen Operationen eine Pflicht zur Aufklärung über Adhäsionen?}

Authors

Affiliations
A. Hirschelmann ${ }^{1 *}$, C. W. Wallwiener ${ }^{2 *}$, M. Wallwiener ${ }^{3}$, D. Weyhe ${ }^{4}$, G. Tchartchian $^{5}$, A. Hackethal ${ }^{6}$, R. L. De Wilde ${ }^{1}$

The affiliations are listed at the end of the article

\section{Key words \\ - adhesions \\ - adhesion prophylaxis \\ - awareness \\ - patient education \\ - lawsuit}

Schlüsselwörter

- Adhäsionen

- Adhäsionsprophylaxe

- Wahrnehmung

- Aufklärung

- rechtliche Konsequenzen

$\begin{array}{ll}\text { received } & 19.1 .2012 \\ \text { revised } & 17.2 .2012 \\ \text { accepted } & 28.2 .2012\end{array}$

Bibliography

Dol http://dx.doi.org/ 10.1055/s-0031-1298425

Geburtsh Frauenheilk 2012; 72 : 299-304 @ Georg Thieme Verlag KG Stuttgart · New York . ISSN 0016-5751

\section{Correspondence}

Dr. Markus Wallwiener

University Heidelberg

Department of Obstetrics

and Gynecology

Vosstraße 9

69115 Heidelberg

markus.wallwiener@

googlemail.com

\section{Abstract}

$\nabla$

Background: Over the past decades, our knowledge and understanding of adhesions and adhesion-related complications has increasingly grown and it has become evident that adhesions have significant implications for patients, physicians and the healthcare system. The question arises whether this has resulted in greater awareness of adhesion-related problems among practicing physicians and appropriate patient education on this topic in daily practice. The following article provides a brief overview of the important subject of adhesions, discusses current awareness of adhesions among patients and doctors and addresses the consequences of failure to provide patient education and consent from a medical perspective.

Methods: Selective literature searches were conducted in PubMed and the Cochrane Library. A patient information and consent form was developed based on several years' experience and expertise in the field of adhesions.

Results: Adhesions are the most common type of complication in abdominopelvic surgery today, with devastating consequences for some patients. Surveys investigating the awareness of adhesions among physicians and patients clearly showed that even well-informed physicians fail to educate their patients adequately. Such failure could potentially lead to successful medical malpractice lawsuits against doctors.

Conclusion: Considering their clear clinical impact, adhesions and related consequences should always be discussed with patients preoperatively. A newly developed consent form that specifically addresses adhesion formation may serve to thoroughly educate patients preoperatively and to adequately document the process of doing so.

* Joint first authors and equal contributors.

\section{Zusammenfassung \\ $\nabla$}

Hintergrund: In den letzten Jahrzehnten hat das Wissen über Adhäsionen und adhäsionsbedingte Komplikationen stetig zugenommen, wobei gezeigt werden konnte, dass Adhäsionen beträchtliche Folgen für Patienten, Ärzte und das Gesundheitssystem haben. Aufgrund dieser Erkenntnisse stellt sich ärztlicherseits die Frage, ob die Forschungsergebnisse zu einer verstärkten Wahrnehmung von Adhäsionen bei praktisch tätigen Ärzten geführt haben, und es in der Folge auch zu einer verstärkten Aufklärung der Patienten über adhäsionsbedingte Komplikationen gekommen ist. Der vorliegende Artikel gibt einen kurzen Überblick über das wichtige Thema der Adhäsionen und beschäftigt sich mit der Wahrnehmung von Adhäsionen durch Ärzte und Patienten sowie mit den möglichen rechtlichen Konsequenzen einer nicht erfolgten Aufklärung aus ärztlicher Sicht.

Methodik: Für die Erstellung des Artikels wurde eine selektive Literaturrecherche in PubMed und der Cochrane Library durchgeführt. Ferner wurde ein Aufklärungsbogen auf der Grundlage langjähriger Erfahrung und Expertise auf dem Gebiet der Adhäsionen entwickelt.

Ergebnisse: Adhäsionen sind heutzutage die häufigste Komplikation abdominopelviner Operationen mit z.T. schwerwiegenden Auswirkungen für die betroffenen Patienten. Befragungen bez. der Wahrnehmung von Adhäsionen durch Ärzte und Patienten ergaben, dass selbst gut informierte Ärzte ihre Patienten nicht über adhäsionsbedingte Komplikationen aufklären, obgleich dies rechtliche Konsequenzen haben könnte.

Schlussfolgerung: Aufgrund der großen klinischen Bedeutung von Adhäsionen sollten Patienten routinemäßig über Adhäsionen und die potenziell damit verbundenen Komplikationen aufgeklärt werden. Ein neu erstellter Aufklärungsbogen über Adhäsionen kann helfen, Patienten nachweislich und gründlich aufzuklären. 


\section{Background}

Adhesions following surgery have long been known, and the first scientific paper on the subject was written more than 100 years ago [1]. However, an understanding of the fundamental pathomechanisms involved has only been achieved over the last decades. Numerous studies have been performed on the consequences of adhesions for patients as well as on the associated implications for the health system [2-4]. The results of these studies are clear and pose the question of whether the scientific work of the last few decades has influenced awareness of adhesions in daily practice. In particular, surgeons who perform abdominopelvic operations should have a specific interest in the subject since patients should be educated as a matter of course on highincidence complications. The occurrence of adhesions varies from study to study and lies generally between 20 and 93 percent [5-10]. Adhesions can currently be considered the most commonly recorded complication following abdominopelvic surgery. The present article provides a short overview and pays particular attention to the level of awareness of adhesions among physicians and patients. The potential legal consequences of patient education and consent are discussed, and a patient information form developed by the authors is proposed.

\section{Formation of Adhesions}

$\nabla$

Adhesions are bands of connective tissue which join two normally separate anatomical structures. As a reaction to a peritoneal trauma, for instance due to inflammation (inflammatory processes) or surgery, increased vessel permeability occurs during normal healing, resulting in a migration of inflammatory cells and accumulation of fibrin. Among others, fibroblasts also migrate into the fibrin matrix where they produce extracellular matrix components, thereby modifying the fibrin matrix. The accumulated fibrin can normally be broken down by the fibrinolytic system. However, if the fibrin is not degraded due to reduced fibrinolysis, the fibrin matrix becomes the basis for adhesion formation $[11,12]$. In a further process, the initially reversible connective tissue bands can undergo stable reconstruction and become vascularised and innervated $[13,14]$. The formation of adhesions is a complex process involving changes in the fibrinolytic system itself and the various cytokines which influence the fibrinolytic system $[15,16]$. Hypoxia is an important factor. Studies on fibroblasts have shown that collagen synthesis is stimulated under hypoxia conditions, and factors in the fibrinolytic system are influenced in terms of antifibrinolytic activity $[17,18]$. Other influencing factors are the cytokines released during an inflammatory reaction. Increased concentrations of proinflammatory cytokines are found in the peritoneal fluid of patients with adhesions $[19,20]$. These cytokines are capable of stimulating the fibrinolytic system factors, thereby causing an antifibrinolytic effect $[21,22]$. In abdominopelvic surgery, an inflammatory reaction as well as hypoxia can be more marked as a result of an extensive surgical trauma, peritoneal sutures or the use of electrocoagulation. Moreover, laparoscopic interventions can result in damage to the peritoneum through a negative effect of the pneumoperitoneum on the peritoneal cells or dehydration of the cells when using dry insufflation gas. The formation of adhesions is thus stimulated [23-26].

\section{Complications Resulting From Adhesions}

$\nabla$

Adhesions form within 3-5 days; however, complications associated with the adhesions often become clinically relevant and indicate symptoms only some time after the initial operation. One of the most significant complications is mechanical ileus, with adhesions representing the most common aetiology. A recent review of 29 studies investigating the causes of acute ileus indicated that adhesions accounted for $85 \%$ of acute small bowel obstructions. In general, acute ileus is responsible for $5 \%$ of hospital admissions, and $50 \%$ of these cases are treated surgically [27]. Furthermore, adhesions can have a negative impact on fertility. However, only a few studies, some of which are older, have been conducted on the influence of adhesions on fertility [28-30]. Two small, prospective studies have indicated that the use of an adhesion barrier resulted in a higher pregnancy rate in comparison with the control group [31,32]. Other complications caused by adhesions include the development of chronic pelvic pain [33] as well as difficult and prolonged subsequent surgeries with the risk of inadvertent damage to the intestine, blood vessels or urethra $[3,34]$. The considerable costs of treating complications caused by adhesions constitute a burden on the health system $[4,35]$. Considering the significant consequences of adhesions, it is essential that surgeons performing abdominopelvic operations establish a strategy for preventing adhesions. Patients should be informed as a matter of course on the risks associated with adhesions and ways of minimising these risks.

\section{Prevention of Adhesions}

$\nabla$

In addition to meticulous surgical techniques and careful handling of connective tissues, strategies for minimising the risk of adhesion formation include reduced suturing and minimised tissue trauma by limited use of electrocoagulation. Coagulation time and frequency should be reduced, and aerosolised tissue arising from electrocoagulation should be aspirated. Foreign bodies, such as materials with loose fibres, should be avoided. The use of wet instead of dry cloths or sponges and the use of starchfree and latex-free gloves during laparotomy are recommended measures. A reduction of pressure and duration of the pneumoperitoneum during laparoscopy can limit the occurrence of adhesions. The peritoneum should be thoroughly rinsed during laparoscopy as well as laparotomy in order to reduce dehydration of the peritoneal cells [36].

Currently there is no certain way of predicting which operations and which patients will present with symptomatic adhesions. Adhesion prophylaxis should be considered in the form of antiadhesion devices following abdominopelvic surgery. Currently no systemic pharmaceutical products are available for reducing adhesions. All available products are designed to mechanically separate the injured tissue from the surrounding organs during the healing process. There is no doubt that these products can in principle reduce adhesions following abdominopelvic surgery. However, current data do not clearly indicate the factor by which a reduction is possible because the reductions achieved vary depending on the device used and the study undertaken. A large, randomised, double-blind study $(n=402)$ comparing the use of an adhesion barrier with a purely Ringer lactate solution instillation indicated a significant difference in the reduction of new adhesions. In the treatment group $(n=203), 47 \%$ of patients developed new adhesions compared with $57 \%$ in the control group 
$(\mathrm{n}=199)$. In this study, clinical success was defined as a reduction in the number of sites of adhesion occurrence of at least 3 or $30 \%$ following adhesiolysis. In the treatment group, clinical success was recorded in $49 \%$ of patients compared with $38 \%$ in the control group. In the subgroup of infertile female patients, $55 \%$ in the treatment group $(n=102)$ indicated clinical success compared with $33 \%$ in the control group $(n=112)$ [37]. A further large, prospective blind study $(n=546)$ investigated the efficacy of the adhesion barrier following myomectomy. The incidence of adhesions was assessed in a second-look laparoscopy and indicated the following: abdominal myomectomy without adhesion barrier (28.1\%; $n=154)$, laparoscopic myomectomy without adhesion barrier (22.6\%; $\mathrm{n}=155)$, abdominal myomectomy with adhesion barrier ( $22 \% ; n=154)$ and laparoscopic myomectomy with adhesion barrier ( $15.9 \% ; n=157$ ) [6]. Other studies have been the subject of meta-analyses $[38,39]$. Due to uncertainty of the efficacy of anti-adhesion agents, it is difficult for physicians to decide on which agent to use. Moreover, many adhesion barriers are still very expensive and are seldom reimbursed by health funds. A validated, scientific re-evaluation of the efficacy of anti-adhesion products, combined with a thorough patient education are urgently needed in order to establish the use of these products.

\section{Physician Awareness}

$\nabla$

Questions are increasingly being asked about adhesion awareness on the part of the physicians and patients. One might expect that the results of experimental and clinical studies during the past decades would have increased awareness among physicians, and that patients are being better informed on adhesions. The following paragraphs provide an overview of three studies on physician awareness in relation to adhesions. Surgically active gynaecologists in Germany [40] and Great Britain [41] as well as general surgeons and gynaecologists in The Netherlands [42] were surveyed.

In Germany, a questionnaire was sent to all gynaecological clinics and was completed by the respective head physician or one of the specialists. The results of the study indicated a high level of awareness by German gynaecologists. The response rate was $34 \%$ (279/833), suggesting that the questionnaires tended to be completed by physicians with a specific interest in the subject. The majority of surveyed gynaecologists (66\%) confirmed that patients with adhesions made up a significant proportion of their daily surgical activities. Although over $60 \%$ of the respondents agreed that adhesions were accompanied by considerable morbidity in their patients, only $38 \%$ used adhesion barriers in routine practice [40].

In Great Britain, the questionnaire was sent to all members of the Royal College of Obstetricians and Gynaecologists, with a response rate of $10 \%$ (390/4010). About $94 \%$ of the surveyed gynaecologists confirmed that adhesions gave rise to serious consequences and agreed that adhesion barriers should be used in operations with a high risk of adhesion formation. $65 \%$ of the respondents were even of the opinion that adhesion barriers should be used in all operations. When asked about their current anti-adhesion strategy, however, less than $10 \%$ indicated the use of adhesion barriers in their daily routine [41].

The response rate from the Netherlands was 34\% (501/1455) and showed a similar outcome: $67 \%$ of those surveyed confirmed the clinical relevance of adhesions, but only $13 \%$ had used an anti-adhesion agent during the year preceding the survey [42].
In summary, the majority of surgeons were relatively well informed with regard to the individual survey questions, but only a minority actually used adhesion barriers in routine practice. This result emphasises the difficulty in evaluating the benefits of anti-adhesion agents and operations performed according to anti-adhesion standards.

The studies also indicated that even the surveyed surgeons do not inform their patients sufficiently. Only $10 \%$ of the surgeons in the Netherlands stated that they informed their patients about adhesions as a matter of routine, while $41 \%$ stated that they had never mentioned adhesions to their patients. In Great Britain, only $23 \%$ of gynaecologists informed their patients prior to all operations and $38 \%$ prior to some operations. Only $2 \%$ of the respondents offered their patients written information on the subject [40-42]. In Germany, $83 \%$ of the gynaecologists surveyed informed their patients on adhesions. However, a recent prospective study investigating the process of patient education in a German university clinic indicated that adhesions were discussed in only $44 \%$ of consultations. If adhesions are not routinely discussed prior to all abdominopelvic operations, despite the fact that they are common and can have serious consequences, other sources are the only possibility to increase patient awareness of the issue. Ideally, however, the best source of information should be the consultation between doctor and patient.

\section{Patient Awareness and Legal Consequences \\ $\nabla$}

A recent study of the awareness of adhesion by patients conducted in two hospitals in Great Britain and in one Germany university medical centre corroborated the hypothesis that patients are not being sufficiently educated on adhesions [43]. In Germany, $44 \%$ of doctors at the university medical centre discussed adhesions during their patient consultations, but only $39 \%$ of these patients felt satisfactorily informed. In Great Britain, $27 \%$ of patients were informed about adhesions during consultations. The authors assumed that the variance in percentages between Germany and Great Britain was due to the difference in type of consultation. Since no written consent form is used in Great Britain, the authors assumed that doctors often forgot to discuss adhesions. In Germany, on the contrary, written consent forms are used in which adhesions are listed together with other complications. By virtue of this fact, the information rates indicated in Germany are to be considered particularly low. Nevertheless, the study showed that patients who had been informed about adhesions indicated their doctor had been the main source of information. This further emphasises the importance of consultations [43].

An information form specifically aimed at discussing the problem of adhesions is a very useful aid for patient and doctor during a consultation. For the patient, a form written in clear and simple language can help prepare for the discussion with the doctor. For doctors, the routine use of a form can be a reminder to discuss the risk of adhesions with the patient and can provide professional information with which to correctly inform the patient. Professor De Wilde has worked in collaboration with the medical publisher Perimed Fachbuch Verlag to develop an information form focused on adhesions in abdominopelvic operations, see - Fig. 1. An information form can and should never be a substitute for a personal consultation. Nevertheless, it offers patients important information and can serve as evidence for the physician at any time, especially in cases of legal disputes, that the patient was informed about adhesions and the associated complications. 
Guidelines can prompt physicians to discuss serious complications during each consultation, even when the probability of occurrence is low. Less serious complications must be discussed if their occurrence is common [44]. Since a precedence setting case in Great Britain, physicians are deemed negligent if they do not inform patients of complications with a risk of over 1-2\% [45]. Depending on the operation, the 5-year risk of a hospital admission due to complications caused by adhesions lies well over the $1-2 \%$ risk factor [46]. Nevertheless, a study conducted in Great Britain indicates that complications caused by adhesions are only noted on $9 \%$ of information forms [47].

The number of successful lawsuits due to adhesion-related complications is increasing [48]. It is in the interests of surgeons, therefore, to be prepared for potential claims and to be in a position to provide evidence that patients are routinely informed on possible complications from adhesions. This is particularly important since a reversal of evidence may be imposed by law in Germany by virtue of which the physician is obliged to provide proof of informing the patient [49].

\section{Conclusion}

$\nabla$

Adhesions are of major clinical significance and should be considered to be the most frequent complication following abdominopelvic surgery. Although physicians consider the issue important, a considerable number of patients are not being routinely informed about adhesions and the potential associated complications. It is in the interests of patients and physicians to educate patients on the risks of adhesions and on the currently available preventive measures. Although the information form cannot and should not be a substitute for a personal consultation, it is a very useful communication aid between physician and patient and serves as documentary evidence of the consultation.

\section{Five Key Statements}

- Today, adhesions are the most common complications following abdominopelvic operations.

- Adhesions potentially have serious consequences for patients, such as acute small bowel obstruction, infertility, chronic pelvic pain and complications during follow-on operations.

- A sound surgical technique and the use of laparoscopy cannot totally prevent the formation of adhesions; the use of adhesion barriers in abdominopelvic operations should be considered.

- Currently, patients are not being sufficiently informed about adhesions and the potential resulting complications; this may lead to successful lawsuits against treating physicians.

- Prior to any abdominal operation, patients should be routinely informed about adhesions by means of a written consent form.
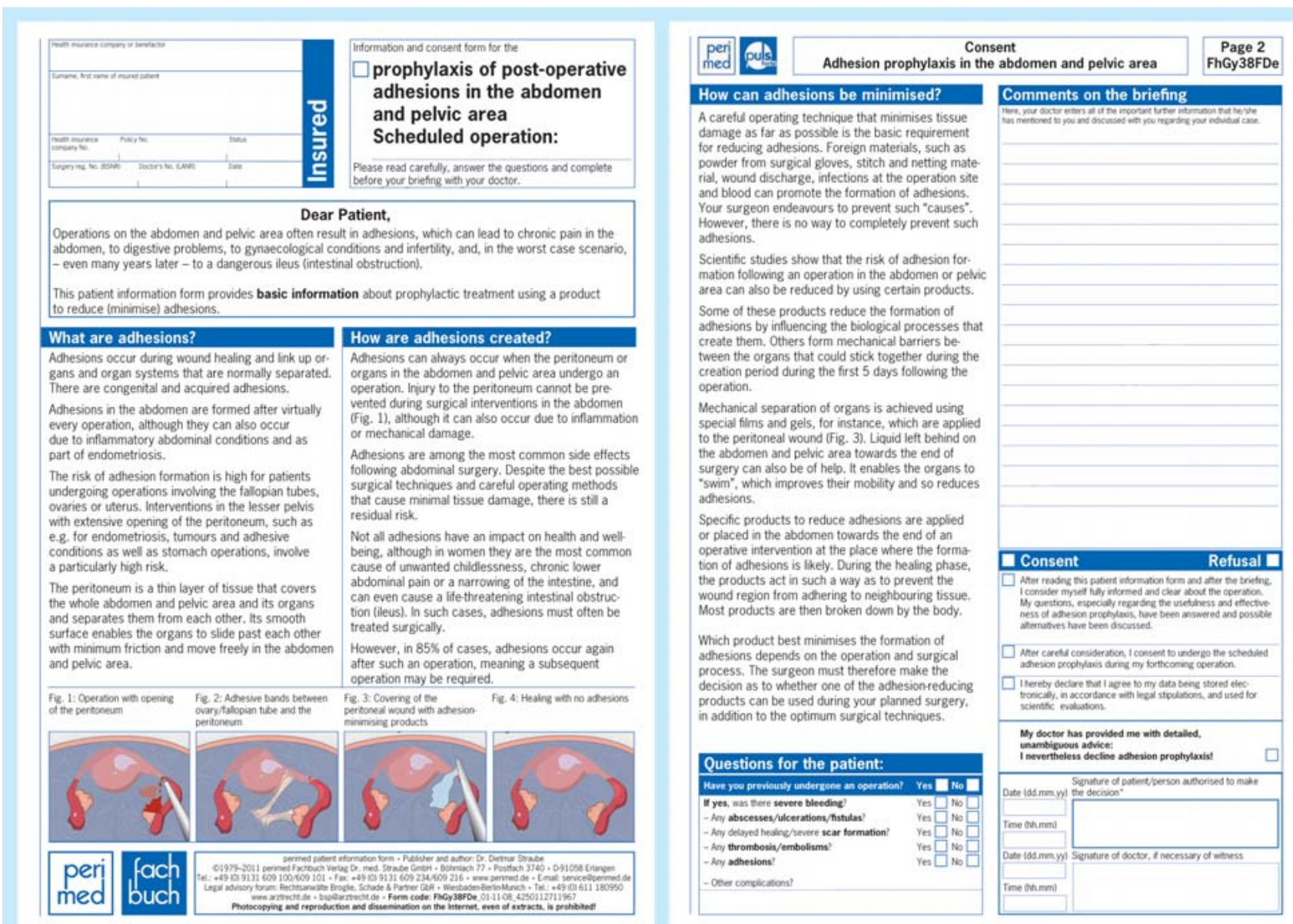

Fig. 1 Perimed information form. 


\section{Conflict of Interest}

\section{$\nabla$}

Professor De Wilde is a scientific consultant for Nordic Pharma $\mathrm{GmbH}$, perimed Fachbuch Verlag Dr. med. Straube GmbH, Baxter $\mathrm{GmbH}$ and Shire GmbH. Dr. Hackethal is a scientific consultant for Nordic Pharma, Fisher \& Paykel Healthcare and Ethicon EndoSurgery.

\section{Affiliations}

${ }^{1}$ Department of Gynaecology, Obstetrics and Gynaecological Oncology, Pius-Hospital, Oldenburg

2 Division of Gynaecological Surgery, Department of Obstetrics and Gynaecology, University of Tübingen, Tübingen

${ }^{3}$ Department of Obstetrics and Gynaecology, University of Heidelberg, Heidelberg

${ }^{4}$ Department of General and Visceral Surgery, Pius-Hospital, Oldenburg

${ }^{5}$ Clinic for Minimal Invasive Surgery, Berlin-Zehlendorf

${ }^{6}$ Queensland Centre for Gynaecological Cancer, Royal Brisbane and Women's Hospital, Herston, Queensland, Austria

\section{References}

1 Uhlmann C. Ueber das Auftreten peritonealer Adhäsionen nach Laparotomien, mit besonderer Berücksichtigung des Verhältnisses zwischen trockener und feuchter Asepsis. Arch Gynecol Obstet 1897; 54: 384411

2 Ellis H, Moran B, Thompson J et al. Adhesion-related hospital readmissions after abdominal and pelvic surgery: a retrospective cohort study. Lancet 1999; 353: 1476-1480

3 van der Krabben AA, Dijkstra FR, Nieuwenhuijzen M et al. Morbidity and mortality of inadvertent enterotomy during adhesiotomy. Br J Surg 2000; 87: 467-471

4 Wilson MS, Menzies D, Knight AD et al. Demonstrating the clinical and cost effectiveness of adhesion reduction strategies. Colorect Dis 2002; 4: 355-360

5 Dubuisson J, Botchorishvili R, Perrette S et al. Incidence of intraabdominal adhesions in a continuous series of 1000 laparoscopic procedures. Am J ObstetGynecol 2010; 203: 111.e1

6 Tinelli A, Malvasi A, Guido M et al. Adhesion formation after intracapsular myomectomy with or without adhesion barrier. Fertil Steril 2011; 95: $1780-1785$

7 Takeuchi H, Kitade M, Kikuchi I et al. Influencing factors of adhesion development and the efficacy of adhesion-preventing agents in patients undergoing laparoscopic myomectomy as evaluated by a second-look laparoscopy. Fertil Steril 2008; 89: 1247-1253

8 Brill AI, Nezhat F, Nezhat CH et al. The incidence of adhesions after prior laparotomy: a laparoscopic appraisal. Obstet Gynecol 1995; 85: 269272

9 Mercorio F, Mercorio A, Di Spiezio Sardo A et al. Evaluation of ovarian adhesion formation after laparoscopic ovarian drilling by second-look minilaparoscopy. Fertil Steril 2008; 89: 1229-1233

10 Menzies D, Ellis H. Intestinal obstruction from adhesions-how big is the problem? Ann R Coll Surg Eng 1990; 72: 60-63

11 di Zerega GS, Campeau JD. Peritoneal repair and post-surgical adhesion formation. Hum Reprod Update 2001; 7: 547-555

12 Imudia AN, Kumar S, Saed GM et al. Pathogenesis of intra-abdominal and pelvic adhesion development. Semin Reprod Med 2008; 26: 289297

13 Herrick SE, Mutsaers SE, Ozua P et al. Human peritoneal adhesions are highly cellular, innervated, and vascularized. J Pathol 2000; 192: 67-72

14 Tulandi T, Fong Chen M, Al-Took S et al. A study of nerve fibers and histopathology of postsurgical, postinfectious, and endometriosis-related adhesions. Obstet Gynecol 1998; 92: 766-768

15 Cheong YC, Laird SM, Li TC et al. Peritoneal healing and adhesion formation/reformation. Hum Reprod Update 2001; 7: 556-566

16 Hellebrekers BW, Kooistra T. Pathogenesis of postoperative adhesion formation. Br J Surg 2011; 98: 1503-1516

17 Saed GM, Diamond MP. Hypoxia-induced irreversible up-regulation of type I collagen and transforming growth factor- $\beta 1$ in human peritoneal fibroblasts. Fertil Steril 2002; 78: 144-147

18 Saed GM, Diamond MP. Modulation of the expression of tissue plasminogen activator and its inhibitor by hypoxia in human peritoneal and adhesion fibroblasts. Fertil Steril 2003; 79: 164-168
19 Cheong YC, Shelton JB, Laird SM et al. IL-1, IL-6 and TNF- $\alpha$ concentrations in the peritoneal fluid of women with pelvic adhesions. Hum Reprod Update 2002; 17: 69-75

20 Cheong YC, Laird SM, Shelton JB et al. The correlation of adhesions and peritoneal fluid cytokine concentrations: a pilot study. Hum Reprod Update 2002; 17: 1039-1045

21 Sitter T, Toet K, Fricke $H$ et al. Modulation of procoagulant and fibrinolytic system components of mesothelial cells by inflammatory mediators. Am J Physiol 1996; 271 (5 Pt 2): R1256-R1263

22 Tietze L, Elbrecht A, Schauerte C et al. Modulation of pro- and antifibrinolytic properties of human peritoneal mesothelial cells by transforming growth factor beta1 (TGF-beta1), tumor necrosis factor alpha (TNF-alpha) and interleukin 1beta (IL-1beta). Thromb Haemost 1998; 79: $362-370$

23 Molinas CR, Mynbaev O, Pauwels A et al. Peritoneal mesothelial hypoxia during pneumoperitoneum is a cofactor in adhesion formation in a laparoscopic mouse model. Fertil Steril 2001; 76: 560-567

24 Molinas CR, Elkelani O, Campo R et al. Role of the plasminogen system in basal adhesion formation and carbon dioxide pneumoperitoneumenhanced adhesion formation after laparoscopic surgery in transgenic mice. Fertil Steril 2003; 80: 184-192

25 Binda MM, Molinas CR, Hansen P et al. Effect of desiccation and temperature during laparoscopy on adhesion formation in mice. Fertil Steril 2006; 86: 166-175

26 Brokelman WJ, Holmdahl L, Janssen IM et al. Decreased peritoneal tissue plasminogen activator during prolonged laparoscopic surgery. J Surg Res 2009; 151: 89-93

27 O'Connor DB, Winter DC. The role of laparoscopy in the management of acute small-bowel obstruction: a review of over 2,000 cases. Surg Endosc 2012; 26: 12-17

28 Caspi E, Halperin Y. Surgical management of periadnexal adhesions. Int J Fertil 1981; 26: 49-52

29 Tulandi T, Collins JA, Burrows E et al. Treatment-dependent and treatment-independent pregnancy among women with periadnexal adhesions. Am J Obstet Gynecol 1990; 162: 354-357

30 Strandell A, Bryman I, Janson PO et al. Background factors and scoring systems in relation to pregnancy outcome after fertility surgery. Acta Obstet Gynecol Scand 1995; 74: 281-287

31 Sawada T, Nishizawa H, Nishio E et al. Postoperative adhesion prevention with an oxidized regenerated cellulose adhesion barrier in infertile women. J Reprod Med 2000; 45: 387-389

32 Pellicano M, Guida M, Bramante S et al. Reproductive outcome after autocrosslinked hyaluronic acid gel application in infertile patients who underwent laparoscopic myomectomy. Fertil Steril 2005; 83: 498-500

33 Hammoud A, Gago LA, Diamond MP. Adhesions in patients with chronic pelvic pain: a role for adhesiolysis? Fertil Steril 2004; 82: 1483-1491

34 Kumakiri J, Kikuchi I, Kitade $M$ et al. Incidence of complications during gynecologic laparoscopic surgery in patients after previous laparotomy. J Minim Invasive Gynecol 2012; 17(4): 480-486

35 Tingstedt B, Isaksson J, Andersson R. Long-term follow-up and cost analysis following surgery for small bowel obstruction caused by intra-abdominal adhesions. Br J Surg 2007; 94: 743-748

36 De Wilde RL, Trew G. Postoperative abdominal adhesions and their prevention in gynaecological surgery. Expert consensus position. Part 2 steps to reduce adhesions. Gynecol Surg 2007; 4: 243-253

37 Brown CB, Luciano AA, Martin D et al. Adept (icodextrin 4\% solution) reduces adhesions after laparoscopic surgery for adhesiolysis: a double-blind, randomized, controlled study. Fertil Steril 2007; 88: 14131426

38 Metwally ME, Watson A, Lilford $R$ et al. Fluid and pharmacological agents for adhesion prevention after gynaecological surgery. Cochrane Database Syst Rev 2006; 2: CD001298

39 Ahmad G, Duffi JM, Farquhar C et al. Barrier agents for adhesion prevention after gynaecological surgery. Cochrane Database Syst Rev 2008; 2: CD000475

40 Hackethal A, Sick C, Brueggmann D et al. Awareness and perception of intra-abdominal adhesions and related consequences: survey of gynaecologists in German hospitals. Eur J Obstet Gynecol Reprod Biol 2010; 150: 180-189

41 Trew G, Cooke I, Lower A et al. Post-operative abdominal adhesions awareness of UK gynaecologists - a survey of members of the Royal College of Obstetricians and Gynaecologists. Gynecol Surg 2009; 6: 25-37 
42 Schreinemacher MH, ten Broek RP, Bakkum EA et al. Adhesion awareness: a national survey of surgeons. World J Surg 2010; 34: 2805-2812

43 Kraemer B, Birch JC, Birch JV et al. Patients' awareness of postoperative adhesions: results from a multi-centre study and online survey. Arch Gynecol Obstet 2011; 283: 1069-1073

44 General Medical Council. Consent: patients and doctors making decisions together. http://www.gmc-uk.org/static/documents/content/ Consent_0510.pdf; last access: 9.2.2012

45 NHS Litigation Authority. Informed Consent. NHSLA Risk Alert 2004; Issue: 4. http://www.nhsla.com/NR/rdonlyres/AD7A7848-E9A3-4668839F-43E54BBFA3A1/0/RiskManagementAlert4.pdf; last access: 9.2.2012

46 Stanciu D, Menzies $D$. The magnitude of adhesion-related problems. Colorect Dis 2007; 9 (Suppl. 2): 35-38
47 Rajab TK, Wallwiener M, Talukdar S et al. Adhesion-related complications are common, but rarely discussed in preoperative consent: a multicenter study. World J Surg 2009; 33: 748-750

48 Ellis $\mathrm{H}$, Crowe A. Medico-legal consequences of post-operative intra-abdominal adhesions. Int J Surg 2009; 7: 187-191

49 Informationsdienst Medizinrecht. Beweislast und Beweislastumkehr. http://aerztehaftung.de/Beweislast-und-Beweislastumkehr-imArzthaftungsprozess.html; last access: 9.2.2012

Deutschsprachige Zusatzinformationen mit deutschem Text online abrufbar unter: www.thieme-connect.de/ejournals/toc/gebfra. 